\title{
Structural and non-structural carbohydrates in concentrate supplements of silage-based dairy cow rations. 2. Rumen degradation, fermentation and kinetics
}

\author{
H. DE VISSER, P.L. VAN DER TOGT*, H. HUISERT \& S. TAMMINGA*
}

DLO-Research Institute for Livestock Feeding and Nutrition, P.O.Box 160, NL 8200 AD Lelystad, Netherlands

Received 27 March 1992; accepted 10 August 1992

\begin{abstract}
In an experiment executed as a $4 \times 4$ Latin square, the effects of carbohydrates in concentrate mixtures (starch vs. cell wall constituents) and in rate of rumen degradation (rapid vs. slow) on rumen fermentation and rumen kinetics were studied. In a separate experiment three animals were used to measure the rate of degradation, using nylon bag incubations. Four ruminally cannulated dairy cows were used to study rumen fermentation pattern, while rumen kinetics was measured in three of these animals. The basal diets, which comprised $75 \%$ of total dry matter, consisted of wilted grass silage, maize silage and concentrates. The remainder consisted of barley (B), maize (M), pressed ensiled beet pulp (P) or moist ensiled maize bran (MB). All diets were fed as totally mixed rations (TMR). The $\mathrm{pH}$ of the rumen fluid and the total concentration of volatile fatty acids (tVFA) did not differ among diets. The major volatile fatty acids did differ between diets and were expressed as the non-glucogenic glucogenic ratio (NGR), being lowest for diet B and highest for diet P. Differences in NGR could be explained by differences in the rate of degradation of starch and/or NDF, using nylon bag incubations. Concentrations of ammonia and the branched chain fatty acids (BCFA) were higher for diet MB and corresponded with the availability of nitrogen and energy for microbial protein synthesis, which was also reflected in the amount of bacterial protein in the rumen. Degradability was lower for maize starch compared to starch from barley. The rate of digestion measured with nylon bag incubations and from rumen evacuations were similar for $\mathrm{OM}$ and $\mathrm{N}$, but the nylon bag showed a lower estimate for starch and NDF. The large particle fraction of mean total rumen contents mainly consisted of cell wall constituents and did not differ between diets.
\end{abstract}

Keywords: cow, rumen, degradability, fermentation, kinetics, carbohydrates

\section{Introduction}

Dairy cows can only produce high milk yields if their intermediary metabolism is supplied with sufficient nutrients (glycogenic, ketogenic, aminogenic nutrients, min-

* Present address: Department of Animal Nutrition, Wageningen Agricultural University, Haagsteeg 4, NL 6708 PM Wageningen, Netherlands. 


\section{CARBOHYDRATES IN SILAGE-BASED DAIRY COW RATIONS. 2}

erals and vitamins). The limited capacity of the dairy cow to consume roughage to meet nutrient requirements necessitates that dairy diets be supplemented with concentrates, especially in early lactation. The inclusion of concentrates in diets changes total dry matter intake, particle size distribution of the rumen content and often the chemical composition of the diet (Bosch, 1991). Changes in the chemical composition of diets is reflected in degradability of the organic matter, fermentation pattern and kinetics of particle digestion and passage in the rumen (Robinson et al., 1987a, 1987b).

Concentrate mixtures are composed of various ingredients and formulations are based on energy and protein values and the costs of individual ingredients. In addition, there is a need for further specification on the basis of the nutrients (eg. acetic acid, propionic acid) they will supply, because these nutrients determine the actual production of lactose, milk fat and milk protein.

De Visser et al. (1980, 1988) reported large differences in feed intake, milk production and milk composition when varying the type of carbohydrates (structural vs. non-structural) in concentrate mixtures. During these experiments an increase of the portion of rapidly fermentable carbohydrates (i.e. starch and sugars) reduced feed (energy) intake and as a result milk output; especially when feeding roughage and concentrates separately. Milk fat content was decreased, which agreed with the shift of rumen fermentation towards more propionic acid (De Visser et al., 1980, 1988, 1991; Robinson et al., 1986, 1987c, 1987d). Within the various types of carbohydrates, such as starch and cell wall constituents differences in rumen degradability and rate of degradation were found among ingredients (Tamminga et al., 1990; Malestijn et al., 1986, 1988; Van Vuuren et al., 1990). However, these observations were made in non-producing or low-producing animals, fed twice daily at moderate levels of intake with roughage and concentrates fed separately. It was therefore decided to study the effect of structural and non-structural carbohydrates in concentrate supplements in high producing animals fed totally mixed rations (TMR) at high levels of intake. In the feeding trial, the effects on feed intake, milk production and milk composition of differences in carbohydrate source (barley, maize, beet pulp or maize bran) were studied (De Visser et al., 1990b). Results of the feeding trial showed differences in milk fat and protein outputs among treatments. The experiment described in this paper complements the study reported previously, aiming to investigate how the different diets of the feeding trial affected rumen fermentation, rumen digestion (in vivo and in sacco) and digestion kinetics.

\section{Material and methods}

The experiment was carried out as a $4 \times 4$ Latin square arrangement of treatments with four Dutch Friesian dairy cows fitted with a rumen cannula. Three of the cows had a large rumen cannula (10 cm internal diameter, Bar Diamond Inc., Parma, ID, USA), while the fourth animal was fitted with a small cannula $(5 \mathrm{~cm}$ internal diameter, Eriks, Alkmaar, NL). The experiment started approximately 3 weeks after parturition and lasted for 5 months.

Cows were tethered in tie-stalls and had free access to block salt and water. To 
prevent ingredient selection diets were offered as TMR prepared in a forage-mixer wagon. The basal diet, which supplied $75 \%$ of the total dry matter (DM) intake, consisted of wilted grass silage ( $25 \%$ ), maize silage $(25 \%)$ and a concentrate mixture $(25 \%)$. In addition, $25 \%$ of the DM consisted either of barley (B), maize (M), moist pressed ensiled beet pulp (P) or moist ensiled maize bran (MB). Both dried ingredients (barley and maize) were included in the concentrate mixture and were

Table 1. Diet ingredients ( $\left.\mathrm{g} \mathrm{kg}^{-1} \mathrm{DM}\right)$, chemical composition of the diets $\left(\mathrm{g} \mathrm{kg}^{-1} \mathrm{DM}\right)$ and the composition of the concentrate mixtures $\left(\mathrm{g} \mathrm{kg}^{-1}\right)$.

\begin{tabular}{|c|c|c|c|c|}
\hline & \multicolumn{2}{|c|}{ Barley } & Pulp & Maize bran \\
\hline \multicolumn{5}{|l|}{ Diets } \\
\hline Wilted grass silage & 250 & 250 & 250 & 250 \\
\hline Maize silage & 250 & 250 & 250 & 250 \\
\hline Cell wall concentrate & - & - & 250 & 250 \\
\hline Barley concentrate & 500 & - & - & - \\
\hline Maize concentrate & - & 500 & - & - \\
\hline Pressed ensiled beet pulp & - & - & 250 & - \\
\hline Moist ensiled maize bran & - & - & - & 250 \\
\hline \multicolumn{5}{|l|}{ Chemical composition of diets } \\
\hline DM & 552 & 555 & 385 & 456 \\
\hline Ash & 78 & 74 & 80 & 69 \\
\hline $\mathbf{N}$ & 31 & 31 & 30 & 31 \\
\hline NDF & 367 & 345 & 438 & 448 \\
\hline ADF & 180 & 173 & 216 & 197 \\
\hline Hemicellulose* & 187 & 172 & 222 & 251 \\
\hline IADF & 38 & 34 & 38 & 36 \\
\hline Starch & 204 & 228 & 84 & 138 \\
\hline Sugars & 44 & 45 & 42 & 36 \\
\hline Acetic acid & 5 & 5 & 10 & 7 \\
\hline Lactic acid & 15 & 15 & 30 & 22 \\
\hline Ammonia & 3 & 3 & 3 & 4 \\
\hline \multicolumn{5}{|l|}{ Composition of concentrates } \\
\hline & \multicolumn{4}{|c|}{ Concentrate mixture } \\
\hline & \multicolumn{2}{|r|}{ barley } & maize & cell wall \\
\hline Potato protein & \multicolumn{2}{|r|}{40} & 40 & 80 \\
\hline Maize gluten & \multicolumn{2}{|r|}{40} & 40 & 80 \\
\hline Coconut expeller & \multicolumn{2}{|r|}{112} & 112 & 215 \\
\hline Linseed expeller & \multicolumn{2}{|r|}{88} & 88 & 170 \\
\hline Soybean hulls & \multicolumn{2}{|r|}{58} & 58 & 115 \\
\hline Barley & \multicolumn{2}{|r|}{490} & - & - \\
\hline Maize & \multicolumn{2}{|r|}{-} & 480 & - \\
\hline Soybean meal solv. extr. & \multicolumn{2}{|r|}{140} & 159 & 290 \\
\hline Calcium carbonate & \multicolumn{2}{|r|}{7} & 7 & 10 \\
\hline Calcium phosphate & \multicolumn{2}{|r|}{3} & 4 & 6 \\
\hline Magnesium oxide & \multicolumn{2}{|r|}{5} & 5 & 10 \\
\hline Premix (vitamins and minerals) & \multicolumn{2}{|r|}{7} & 7 & 14 \\
\hline
\end{tabular}

* hemicellulose is calculated as NDF-ADF. 
CARBOHYDRATES IN SILAGE-BASED DAIRY COW RATIONS. 2

Table 2. Experimental design (rumen fermentation and kinetics).

\begin{tabular}{lllll}
\hline Period & \multicolumn{2}{l}{ Cow numbers } & & \\
\cline { 2 - 4 } & $744^{*}$ & $829^{* *}$ & $843^{* *}$ & $1536^{* *}$ \\
1 & pulp & maize bran & barley & maize \\
2 & maize bran & barley & maize & pulp \\
3 & maize & pulp & maize bran & barley \\
4 & barley & maize & pulp & maize bran \\
\hline
\end{tabular}

* animal only used in the fermentation study

** animals used in the fermentation- as well as the rumen kinetic study

ground. The composition of the diets and the concentrate mixtures are in Table 1 . The animals were fed twice daily with $40 \%$ of the daily allowance at $5.00 \mathrm{~h}$ and $60 \%$ at $14.00 \mathrm{~h}$. Animals were fed ad libitum, but refusals were restricted to a maximum of approximately $2 \%$ as fed. During the four experimental periods individual animals were offered the same amount of dry matter as was consumed by that cow during the first period. The design of the experiment is in Table 2. Each experimental period lasted for 5 weeks. The first 4 weeks were for adaptation to the diets, while during the fifth week of each period the fermentation pattern and rumen kinetics were measured.

During the experimental week samples were taken from all diet ingredients and analysed for dry matter (DM), ash, nitrogen (N), neutral detergent fibre (NDF), acid detergent fibre (ADF), indigestible acid detergent fibre (IADF), sugar and starch. The analytical methods used were as described by Robinson et al. (1986) and De Visser \& Hindle (1990a).

\section{Rumen fermentation}

During the experimental week the fermentation pattern was determined for 48 hours by taking 17 samples of the rumen fluid as described by De Visser et al. (1991). The samples were taken at 5.00,7.00,10.00,14.00,16.00,19.00,22.00, 2.00 and 5.00 hours, respectively, and immediately analysed for $\mathrm{pH}$ with a $\mathrm{pH}$ meter (Yokoyama). Subsamples were taken and stored for analysis of volatile fatty acids (VFA), lactic acid (HL) and ammonia $\left(\mathrm{NH}_{3}-\mathrm{N}\right)$ as described by Robinson et al. (1986). The ratio between the non-glucogenic and glucogenic fatty acids (NGR) was calculated according to the method as described by Ørskov et al. (1975), except that lactic acid was considered as a glucogenic precursor.

The diurnal pattern of feed and water intake was recorded.

Analysis of variance using cow, period and diets as variables influencing rumen parameters was completed with mean daily values (weighted for time intervals) and daily variations (expressed as standard deviation of daily values), using the statistical package Genstat (Alvey et al., 1982). 


\section{Rumen kinetics}

The three dairy cows with the large rumen cannula were used for measuring rumen ingesta mass, composition and kinetics. Average rumen mass was measured by manual evacuation on three occasions $(4.00 \mathrm{~h}, 10.00 \mathrm{~h}$ and $20.00 \mathrm{~h})$, while the animals had access to feed. The method of evacuation was as described by Robinson et al. (1987b).

Two samples of total rumen mass were taken at each sampling time. The first was freeze dried and analysed for ash, N, NDF, ADF, IADF, starch and diaminopimelic acid (DAPA). The second was placed in a large nylon bag $(25 \times 40 \mathrm{~cm})$ with a pore size of $2 \mathrm{~mm}$ and washed twice in a washing machine for 55 minutes with cold water, without washing powder and spin drying (wool wash programme). The residue after washing was removed from the bag, freeze dried and analysed for ash, $\mathrm{N}$, NDF, ADF and IADF. Total rumen pool and pool of particles $>2 \mathrm{~mm}$ (OM, NDF, ADF, IADF) were measured, while the pool of particles $<2 \mathrm{~mm}$ was calculated by subtraction.

Rumen bacteria were isolated by differential centrifugation, freeze dried and analysed for $\mathrm{N}$ and DAPA, as described by Robinson et al. (1987a). By calculation, total rumen $\mathrm{N}$ pool (NAN) was separated into a bacterial $\mathrm{N}$ and a residual $\mathrm{N}$ fraction.

Kinetics of rumen OM, N, starch, NDF and ADF clearance, passage and digestion were calculated as:

- rate of clearance $\left(k_{\mathrm{c}}\right)=\left(\left(\right.\right.$ feed intake, $\left.\mathrm{kg} \mathrm{d}^{-1}\right) /($ average rumen pool, $\left.\mathrm{kg})\right) / 24$

- rate of passage $\left(\mathrm{k}_{\mathrm{p}}\right)=\left(\left(\right.\right.$ IADF intake, $\left.\mathrm{kg} \mathrm{d}^{-1}\right) /($ average rumen IADF pool, $\left.\mathrm{kg})\right) / 24$

- rate of digestion $\left(k_{d}\right)=\left(k_{c}-k_{p}\right)$

Kinetics of rumen OM, NDF and IADF of the large particle fraction were also calculated using the same equations. The clearance of the large particles was calculated with the assumption that the concentrate part of the diet (concentrate mixtures and by-products) only consisted of small particles $(<2 \mathrm{~mm})$. The NDF and IADF of the roughage components (i.e. grass silage and maize silage) were assumed to be part of the large particle fraction. As a result of these assumptions both large particle cell wall fractions (NDF, IADF) of the rumen contents can only originate from the roughage components of the diet.

Because of the number of animals with a large rumen cannula (3), the design of the experiment was not completely orthogonally balanced (Table 2). Analysis of variance was performed, using cow, period and diets as variables determining rumen kinetic parameters, using the statistical package Genstat (Alvey et al., 1982). The missing values of the fourth animal were estimated as part of the statistical analysis.

\section{Rumen degradability}

After the rumen fermentation and kinetic study was completed the three animals with the large rumen cannulas were used to measure in sacco rumen OM degradation of all diet ingredients as described by Van Vuuren et al. (1989). Animals were fed the average of all four diets of the rumen fermentation study (Table 1) by mixing these diets in the forage mixer wagon. Results for the individual ingredients were used to 


\section{CARBOHYDRATES IN SILAGE-BASED DAIRY COW RATIONS. 2}

calculate the rate of degradation of the OM, N, NDF and starch of total diets.

The times of incubation were $0,2,4,8,12,24,48,72$ and 336 hours.

The OM fraction was divided into a soluble $(\mathrm{S})$, undigestible $(\mathrm{U})$ and a potentially digestible $(\mathrm{D}=100-\mathrm{S}-\mathrm{U})$ fraction. The rate constant $\left(\mathrm{k}_{\mathrm{d}}\right)$ of $\mathrm{D}$ was estimated by iteration.

\section{Results}

Starch-rich diets (B, M) contained more starch and less NDF than both cell wall diets (P, MB) (Table 1). Diets were similar for N, ash, IADF and sugar contents. During the last experimental period of the rumen fermentation study animal 744 suffered from tarsitis, so feed intake was dramatically reduced. Therefore fermentation characteristics of that animal were omitted and were estimated during statistical analysis.

Table 3. Rumen $\mathrm{pH}$ and concentrations of volatile fatty acids, lactic acid, ammonia $\left(\mathrm{mMol} / \mathrm{l}^{-1}\right)$, between diets barley (B), maize (M), beet pulp (P) and maize bran (MB).

\begin{tabular}{lccccc}
\hline & Barley & Maize & Pulp & Maize bran & SED \\
DM intake $\left(\mathrm{kg} \mathrm{day}^{-1}\right)$ & 24.0 & 23.1 & 22.9 & 24.2 & 0.7 \\
$\mathrm{pH}$, mean & 5.73 & 5.76 & 5.77 & 5.70 & 0.037 \\
$\mathrm{pH}$, range & 0.28 & 0.27 & 0.23 & 0.22 & 0.019 \\
Total VFA, mean & 142 & 142 & 145 & 146 & 3.62 \\
Total VFA, range & 14 & 13 & 13 & 11 & 1.14 \\
NGR*, mean & $3.35^{\mathrm{a}}$ & $3.50^{\mathrm{a}}$ & $3.99^{\mathrm{b}}$ & $3.59^{\mathrm{a}}$ & 0.26 \\
NGR, range & 0.23 & 0.25 & 0.18 & 0.16 & 0.02 \\
& & & & & \\
Lactate, mean & 1.13 & 1.70 & 1.69 & 0.85 & 0.34 \\
Lactate, range & 1.43 & 2.66 & 3.16 & 1.16 & 0.86 \\
Ammonia, mean & $7.46^{\mathrm{a}}$ & $8.36^{\mathrm{ab}}$ & $7.27^{\mathrm{a}}$ & $9.45^{\mathrm{b}}$ & 0.96 \\
Ammonia, range & 4.45 & 4.71 & 4.09 & 4.07 & 0.32 \\
Acetate, mean & 86 & 85 & 92 & 90 & 2.75 \\
Acetate, range & $7^{\mathrm{a}}$ & $6^{\mathrm{a}}$ & $8^{\mathrm{b}}$ & $6^{\mathrm{a}}$ & 0.52 \\
Propionate, mean & 35 & 35 & 32 & 35 & 2.07 \\
Propionate, range & 5 & 4 & 4 & 3 & 0.59 \\
Butyrate, mean & 17 & 18 & 17 & 17 & 0.53 \\
Butyrate, range & 2.5 & 2.7 & 1.9 & 1.8 & 0.42 \\
BCFA, mean & $4.11^{\mathrm{a}}$ & $4.37^{\mathrm{b}}$ & $3.36^{\mathrm{c}}$ & $4.43^{\mathrm{b}}$ & 0.11 \\
BCFA, range & 0.15 & 0.21 & 0.15 & 0.21 & 0.05 \\
\hline
\end{tabular}

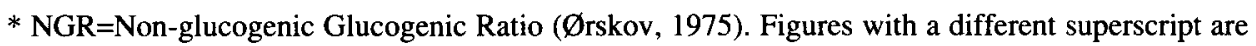
significantly different $(\mathrm{p}<0.05)$. $\mathrm{SED}=$ standard error of difference. $\mathrm{BCFA}=$ branched chain fatty acids (iso-butyrate+2-3 Methyl butyrate+valerate). Mean=mean daily values (weighted for time intervals). Range $=$ calculated as standard deviation (sd) of daily values. 


\section{Rumen fermentation}

During the rumen fermentation study the average intake of diets $\mathrm{M}$ and $\mathrm{P}$ tended to be lower than those of diets $\mathrm{B}$ and $\mathrm{MB}$ (Table 3). Mean daily $\mathrm{pH}$ and concentrations of total VFA and butyrate were similar for all diets. The NGR was significantly higher as was the concentration of BCFA (branched chain fatty acids) lower for diet $P$. The concentration of acetic acid tended to be higher, while the concentration of propionic acid tended $(\mathrm{p}<0.07)$ to be lower at diet $\mathrm{P}$, compared to the other diets $(\mathrm{B}$, $\mathrm{M}$ and $\mathrm{MB}$ ). The concentration of ammonia was significantly higher at diet MB. The concentration of BCFA was lowest for diet $\mathrm{P}$, while diets $\mathrm{M}$ and $\mathrm{MB}$ were higher, compared to diet $\mathrm{B}$.

\section{Rumen kinetics}

Total DM intakes were lower at diets $M$ and $P$ (Table 4). Although DM intake differed among diets, total ingesta, dry matter and non-dry matter contents did not differ significantly between diets. DM percentage of total rumen mass tended to be lower for cows fed diet $P$.

Table 4. Rumen kinetic study ( 3 cows). Total dry matter intake and the daily mean rumen pool sizes of dry matter, organic matter, nitrogen, starch and cell wall constituents.

\begin{tabular}{lccccc}
\hline & Barley & Maize & Pulp & Maize bran & SED \\
DM intake (kg) & $22.7^{\mathrm{a}}$ & $21.1^{\mathrm{b}}$ & $21.1^{\mathrm{b}}$ & $23.9^{\mathrm{c}}$ & 0.6 \\
Bodyweight (kg) & 612 & 610 & 615 & 630 & \\
DM pool/kg bodyweight (g) & 19.9 & 18.9 & 20.0 & 20.5 & \\
Total rumen contents & & & & & \\
Non-dry matter (kg) & 67.2 & 64.0 & 72.6 & 72.4 & 3.7 \\
Dry matter $(\mathrm{kg})$ & 12.2 & 11.5 & 12.3 & 12.9 & 0.9 \\
Total ingesta (kg) & 79.4 & 75.5 & 84.9 & 85.3 & 4.5 \\
Percentage DM & 15.3 & 15.2 & 14.4 & 15.1 & 0.5 \\
Rumen pool sizes & & & & & \\
OM (kg) & 11.2 & 10.6 & 11.2 & 11.9 & 0.8 \\
NAN (g) & 385 & 364 & 394 & 374 & 15.3 \\
Bacterial N (g) & 211 & 210 & 215 & 202 & 9.4 \\
Starch (g) & $424^{\mathrm{a}}$ & $610^{\mathrm{b}}$ & $374^{\mathrm{a}}$ & $382^{\mathrm{a}}$ & 28.8 \\
NDF (kg) & 6.9 & 6.4 & 6.7 & 7.5 & 0.4 \\
ADF (kg) & 3.8 & 3.6 & 3.7 & 4.0 & 0.4 \\
IADF (kg) & 1.2 & 1.1 & 1.2 & 1.2 & 0.1 \\
DADF (kg) & 2.6 & 2.5 & 2.5 & 2.8 & 0.2 \\
Hemicellulose, kg & $3.1^{\mathrm{a}}$ & $2.7^{\mathrm{a}}$ & $3.0^{\mathrm{a}}$ & $3.5^{\mathrm{b}}$ & 0.1 \\
Rumen pool sizes of large particles $(>2 \mathrm{~mm})$ & & & & \\
OM (kg) & 5.5 & 5.1 & 5.4 & 5.7 & 0.6 \\
NDF (kg) & 4.5 & 4.2 & 4.3 & 4.7 & 0.6 \\
ADF (kg) & 2.5 & 2.4 & 2.4 & 2.6 & 0.4 \\
IADF (kg) & 0.6 & 0.6 & 0.6 & 0.7 & 0.1 \\
\hline Values with a diferent & & & & &
\end{tabular}

Values with a different superscript are significantly different $(\mathrm{p}<0.05)$ 


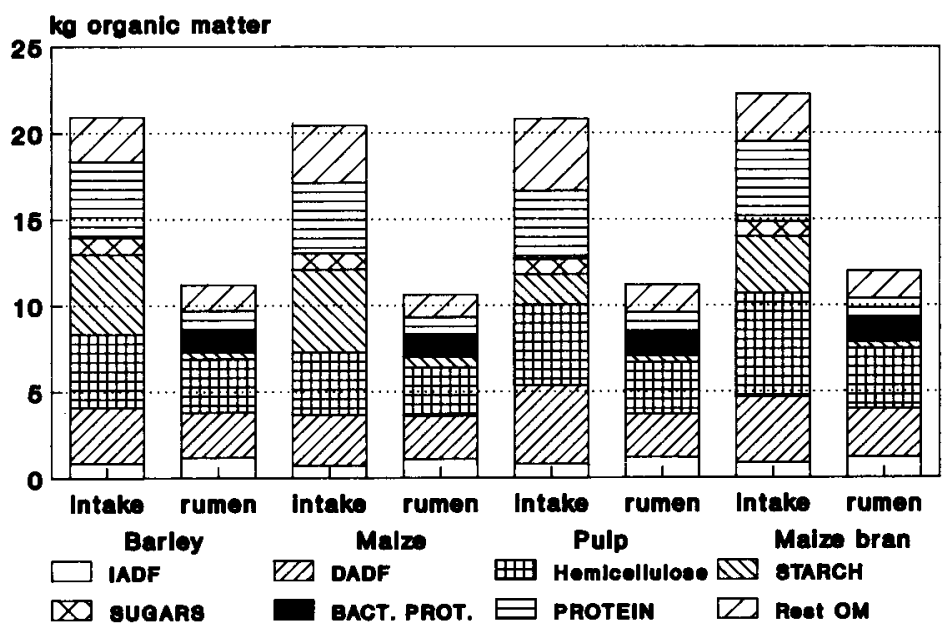

Fig. 1. Composition of OM intake and rumen pool.

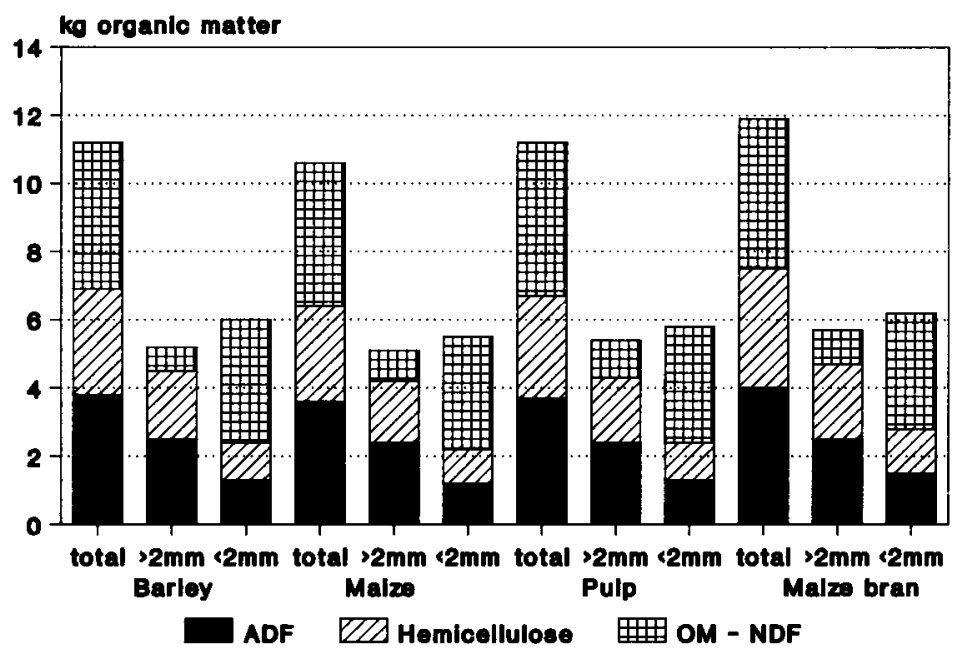

Fig. 2. Partition of OM, hemicellulose and ADF of the rumen pool.

The rumen pool of the OM, total and bacterial $\mathrm{N}$ and the cell wall constituents (NDF, ADF, IADF, DADF) did not differ significantly between diets. The pool size of hemicellulose was highest for diet $\mathrm{MB}$, as was starch for diet $\mathrm{M}$.

The volumes of the average daily rumen pool of cell wall constituents (NDF, ADF) were almost equal to cell wall constituent intakes, whereas that of starch, sugars and total-N were lower (Fig. 1). Approximately $48 \%$ of total rumen OM content consisted of large particles $(>2 \mathrm{~mm}$ ). Fractions (OM, NDF, ADF) were 
similar for all diets. The large particle fraction mainly consisted of cell wall constituents (approximately $80 \%)$, whereas the small particle fraction $(<2 \mathrm{~mm})$ consisted to a large extent of non-cell wall constituent OM (Fig. 2). The rumen turnover of OM, $\mathrm{NDF}, \mathrm{ADF}, \mathrm{DADF}$, hemicellulose, starch and protein is given in Table 5. The rates of passage as calculated from the ratio between intakes (Table 1; Table 4) and pool sizes of the IADF-data of Table 4, were 2.96, 2.75, 3.04 and $3.00 \% \mathrm{~h}^{-1}$ for diets $\mathrm{B}$, $\mathrm{M}, \mathrm{P}$ and $\mathrm{MB}$, respectively. The rate of digestion of the $\mathrm{OM}$ was similar for all diets, whereas that of NDF, ADF and hemicellulose was highest for both cell wall constituent diets (P, MB). That of starch was highest for cow's fed B and lowest for those fed $P$.

Table 5. Turnover of the organic matter, neutral detergent fibre, acid detergent fibre, digestible acid detergent fibre and hemicellulose calculated from rumen evacuation data

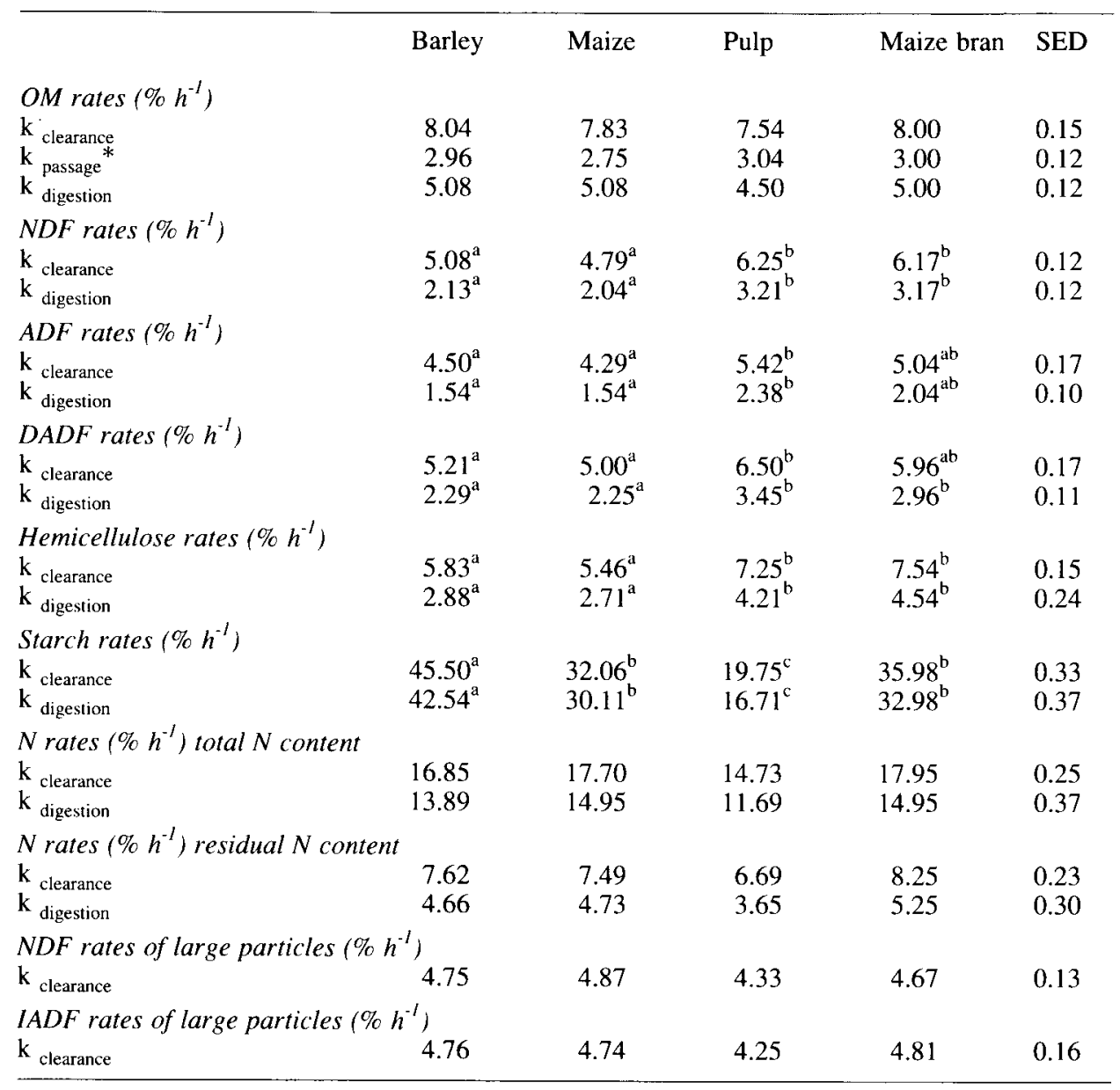

Values with a different superscript are significantly different $(\mathrm{P}<0.05)$.

* $\mathrm{k}_{\text {passage }}$ was calculated from $\mathrm{k}_{\text {clearance }}$ of IADF $\left(\mathrm{k}_{\mathrm{c}}=\mathrm{k}_{\mathrm{p}}\right.$ ) 


\section{Rumen degradation}

The results of calculated rumen degradation, using the nylon bag incubation technique, are given in Table 6. The rate of degradation of OM was highest for diet $\mathrm{B}$ and lowest for diet $\mathrm{MB}$. The $\mathrm{U}$ fraction was similar for all diets, while the $\mathrm{S}$ fraction

Table 6. The soluble (S), potentially fermentable (D), undegradable fraction $(\mathrm{U})\left(\mathrm{g} / \mathrm{kg}^{-1}\right)$ and rate of degradation $\left(\mathrm{k}_{\mathrm{d}}\right)\left(\% \mathrm{~h}^{-1}\right)$ of the organic matter, nitrogen, neutral detergent fibre and starch of the diets barley (B), maize (M), beet pulp (P) and maize bran (MB) and the starch and neutral detergent fibre of the diet ingredients barley, maize, pressed beet pulp and moist ensiled maize bran.

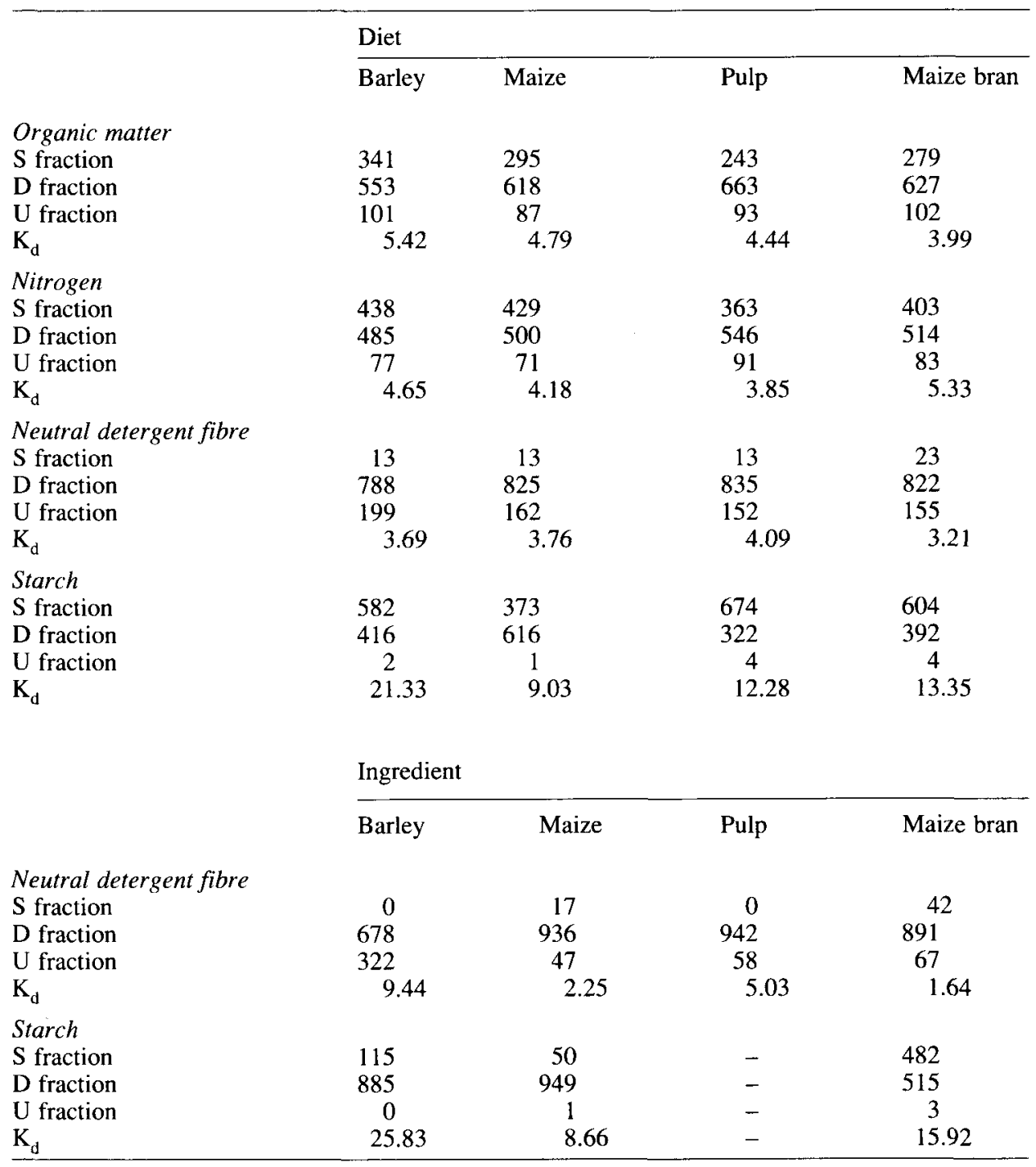


was highest for diet $\mathrm{B}$ and lowest for diet $\mathrm{P}$. The rate of degradation of the NDF was lowest for diet $\mathrm{MB}$, compared to diets $\mathrm{B}, \mathrm{M}$ and $\mathrm{P}$. The rate of degradation of starch was highest for diet $\mathrm{B}$ and lowest for diet $\mathrm{M}$.

\section{Discussion}

Average $\mathrm{pH}$ was lower and average VFA higher than those found by Robinson et al. (1986), feeding comparable levels of starch in the concentrates (up to $320 \mathrm{~g} / \mathrm{kg}^{-1}$ DM). The difference between minimum and maximum, expressed as range in Table 3 , was lower in this experiment. Differences between the latter and this experiment were the lower feed intake (19.5 vs. $22.5 \mathrm{~kg} \mathrm{DM}$ ), the time animals had access to feed and the type and quality of the roughage fed (poor quality hay vs. wilted grass silage and maize silage), percentage of roughage (35 vs. $50 \%$ of total DM) and method of feeding (roughage and concentrates separately vs. TMR).

The $\mathrm{pH}$ of the rumen fluid and the concentration of total VFA was highly correlated $\left(r^{2}=0.92\right)$ and fitted well to the equation derived by Tamminga \& Van Vuuren (1988). In a later experiment (Tamminga, unpublished) it was discovered that rumen fluid contents increased sharply after feeding, resulting in dilution of the VFA and buffering the $\mathrm{pH}$ to decline. In addition, rate of absorption from the rumen increases with higher VFA concentrations (Dijkstra et al., 1992). Hence the ruminant animal has a number of mechanisms which will prevent the average VFA concentration from rising above a maximum of around $150 \mathrm{mMol} / \mathrm{I}^{-1}$ (Robinson et al., 1986, 1987b; Tamminga et al., 1988; De Visser et al., 1991) thereby preventing a $\mathrm{pH}$ drop to values that inhibit rate of degradation. In this experiment, feeding TMR may have slowed the rate of intake of rapidly degradable OM (starch, sugars, soluble protein), enabling the animals to consume large amounts of feed without having too strong negative effects on rumen fermentation, which agrees with results of Rohr \& Schlunsen (1986), who compared TMR against separate feeding of concentrates and roughage.

Although the concentration of total VFA was similar for all diets, there was a difference in the ratio of the major volatile fatty acids and the calculated NGR values. The lower NGR value of diet B compared to diet M corresponded well with the higher rate of degradation of barley starch (Table 6, Tamminga et al., 1990), its higher rate of digestion calculated from rumen evacuation data (Table 5) and nylon bag incubations (Table 6, Tamminga et al., 1990; Malestijn et al., 1988), which agrees with the lower rumen starch pool size (Table 4). As a result, a lower amount of starch probably escaped rumen fermentation, which agrees with the work of Waldo (1973) and Nocek \& Tamminga (1991).

The lowest NGR value of diet B corresponded with its high starch content and its higher measured $k_{d}$ of the OM and starch. The highest NGR-value of diet $P$ agreed with its higher NDF content and lower $k_{d}$ of the OM and NDF (Table 1; Table 6). These findings are consistent with results of Sutton et al. (1987) and Thomas et al. (1986), who fed starchy vs. fibrous concentrates (barley, beet pulp).

It was expected for diet MB and diet $P$ to have similar NGR values, because of the high NDF content (Table 1) and the low rate of degradation of the NDF (Table 6). 
However diet MB contained an higher amount of starch (Table 1), which was relatively rapidly degradable (Table 6), probably due to processing. This resulted in a tendency towards a lower average rumen $\mathrm{pH}$ and caused a shift in fermentation pattern towards propionic acid with a more starchy diet compared to a more fibrous one (Table 3).

The higher concentrations of ammonia and BCFA on diet MB probably were the result of an imbalance between the availability of $\mathrm{N}$ and energy for microbial protein synthesis. This is consistent with the very low $k_{d}$ of the NDF and the higher $k_{d}$ of the nitrogen of diet MB (Table 6), as well as the tendency towards a lower amount of rumen microbial protein (Table 4), which agrees with results reviewed by Nocek \& Russell (1988). The accompanying feeding trial (De Visser et al., 1990b) showed a lower milk protein content for cows fed diet MB, which is consistent with these ruminal data. Also diet $M$ showed a tendency towards a higher concentration of ammonia in the rumen fluid. Starch escaping rumen fermentation results in a lower energy supply for microbes (Van Vuuren et al., 1990), supplementing fresh grass with concentrates based on various carbohydrates varying in rate of degradation, as well as data reviewed by Nocek \& Russell (1988). However, cows fed diet M did not show lower milk protein contents (De Visser et al., 1990b). Our findings of tendencies towards reduced microbial protein synthesis agree with results of Robinson et al. $(1987 \mathrm{c})$, when feeding diets high in ensiled products with fermentation endproducts and thus a reduced amount of energy available for microbial growth. Robinson et al. (1987b) also found a tendency towards lower amounts of microbial protein in the rumen content when decreasing starch in the diet. However, in this experiment this was not confirmed, by comparing diet $\mathrm{P}$ with diets $\mathrm{M}$ and $\mathrm{B}$, probably as the result of the higher quality of the roughage used in this experiment.

Total rumen content as related to bodyweight (BW) did not differ among diets and was approximately $20 \mathrm{~g} \mathrm{~kg}^{-1} \mathrm{BW}$, agreeing with results found and reviewed by Bosch (1991).

The highest rumen starch pool of diet $M$ can be explained by the lower $k_{d}$ of maize starch as compared to starch originating from barley or maize bran (Table 4; Table 6), which agrees with other observations found by Waldo (1973) and reviewed by Nocek \& Tamminga (1991), comparing the digestion of starches in the gastrointestinal tract of dairy cows.

The similar pool size of the cell wall constituents among diets did not reflect the differences in NDF intake. A major part of NDF intake originated from the basal diet and was the same in all diets. Rumen degradation characteristics of NDF from beet pulp and maize bran, although different, were clearly not different enough to result in differences in rumen pool size.

The similar composition of the rumen pool of large particles $(>2 \mathrm{~mm}$, Table 4; Fig. 2) are strongly related to the roughage part of the basal diet fed in all treatments (Table 1). The large particle pool consisted mainly of cell wall constituents (approx. $80 \%$ ), because the other components were part of the more rapidly degradable or soluble fraction, which disappeared from the large particle fraction. Bosch (1991) showed similar data, when comparing grass silages in various stages of maturity.

The $\mathrm{k}_{\text {clearance }}$ of NDF and IADF were similar for large particles ( $>2 \mathrm{~mm}$, Table 5), 
suggesting that disappearance of NDF from the large particle pool was primarily the result of ruminating instead of degradation by micro-organisms, which confirms results of Bosch (1991), Moseley \& Jones (1984), Smith et al. (1983) and Ulyatt et al. (1984).

The similar small particle pool (Fig. 2) was unexpected, because large differences occurred in the composition of these fractions in the diets. Due to the time after feeding the rumen content was evacuated (on average approximately 5 hours after feeding) the more rapidly degradable components (sugars, starch, pectines, fermentation-endproducts) probably were fermented (Table 6) or had disappeared by passage.

The rate of passage of particles, calculated as $\mathrm{k}_{\text {clearan }}$ ce of IADF was similar for all diets (Table 5) and agreed with the rate of passage found by Bosch (1991), De Visser et al. (1992) and Van Vuuren et al. (1992). However, the rate of passage of IADF probably underestimated the rate of passage of other organic components, such as starch.

The calculated rate of digestion of $\mathrm{OM}$ and $\mathrm{N}$ using the method of dacron bag incubations as well as rumen evacuation showed similar data. However, for starch and cell wall constituents the results disagree. The effects of the soluble fraction, rate of passage of particles and average time of rumen evacuation after feeding are probably responsible for the measured differences.

Feeding diets varying in carbohydrate composition and rate of degradation (starch and cell wall constituents) influence the rate of rumen fermentation, the amount of starch escaping rumen fermentation and the balance between energy and nitrogen available for rumen microbial growth. As a result rumen fermentation pattern was changed, which had its effect on milk performance.

\section{References}

Alvey, N., N. Galway, \& P. Lane, 1982. An introduction to Genstat. Academic Press, London, 152 pp.

Bosch, M.W., 1991. Influence of stage of maturity of grass silages on digestion processes in dairy cows. Doctoral Thesis, Wageningen Agricultural University, $150 \mathrm{pp}$.

Malestijn, A. \& A. Th. van 't Klooster, 1986. Influence of ingredient composition of concentrates on rumen fermentation rate in vitro and in vivo and on roughage intake of dairy cows. Journal of Animal Physiology and Animal Nutrition 55: 1-13.

Malestijn, A, A. Th. van 't Klooster \& J.W. Cone, 1988. Degradability of various types of starch by incubation with rumen fluid or with bacterial amylase. Journal of Animal Physiology and Animal Nutrition 59: 225-232.

Moseley, G. \& J.R. Jones, 1984. The physical digestion of perenial ryegrass (Lolium Perenne) and white clover (Trifolium Repens) in the foregut of sheep. British Journal of Nutrition 52: 381-387.

Nocek, J.E. \& J.B. Russell, 1988. Protein and energy as an integrated system. Relationship of ruminal protein and carbohydrate availability to microbial synthesis and milk production. Journal of Dairy Science 71: 2070-2107.

Nocek, J.E. \& S. Tamminga, 1991. Site of digestion of starch in the gastrointestinal tract of dairy cows and its effect on milk yield and composition. Journal of Dairy Science 74: 3598-3629.

Ørskov, E.R., 1975. Manipulation of rumen fermentation for maximum food utilisation. World Review of Nutrition and Dietetics 22: 152-189.

Robinson, P.H., S. Tamminga \& A.M. van Vuuren, 1986. Influence of declining level of feed intake and varying proportion of starch in the concentrate on rumen fermentation in dairy cows. 


\section{CARBOHYDRATES IN SILAGE-BASED DAIRY COW RATIONS. 2}

Livestock Production Science 15: 173-189.

Robinson, P.H., S. Tamminga \& A.M. van Vuuren, 1987a. Influence of declining level of feed intake and varying proportion of starch in the concentrate on milk production and whole tract digestibility in dairy cows. Livestock Production Science 17: 19-35.

Robinson, P.H., S. Tamminga \& A.M. van Vuuren, 1987b. Influence of declining level of feed intake and varying proportion of starch in the concentrate on rumen ingesta quantity, composition and kinetics of ingesta turnover in dairy cows. Livestock Production Science 17: 37-62.

Robinson. P.H., S. Tamminga \& A.M. van Vuuren, 1987c. Influence of wet versus dry by-product ingredients and addition of branched-chain fatty acids and valerate to dairy cows. 2. Rumen fermentation and milk production. Netherlands Journal of Agricultural Science 35: 447-458.

Robinson. P.H., S. Tamminga \& A.M. van Vuuren, 1987d. Influence of wet versus dry by-product ingredients and addition of branched-chain fatty acids and valerate to dairy cows. 3 . Kinetics of rumen digesta turnover, whole tract digestability and some plasma hormone concentrations. Netherlands Journal of Agricultural Science 35: 459-471.

Rohr, K. \& D. Schlunsen, 1986. The bearing of feeding methods on digestion and performance of dairy cows. In: A. Neimann-Sørensen (Ed.). New developments and future perspectives in research on rumen function, p. 227-242. ECSC-EEG-EAEC, Brussels.

Russell, J.B. \& C.J. Sniffen, 1984. Effect of carbon-4 and carbon-5 volatile fatty acids on growth of mixed rumen bacteria in vitro. Journal of Dairy Science 67: 987-994.

Smith, L.W., B.T. Weinland, D.R. Waldo \& E.C. Leffel, 1983. Rate of plant cell wall particle size reduction in the rumen. Journal of Dairy Science 66: 2124-2130.

Sutton, J.D., J.A. Bines, S.V. Morant, D. Napper \& D.I. Givens, 1987. A comparison of starchy and fibrous concentrates for milk production, energy utilization and hay intake by friesian cows. Journal of Agricultural Science (Cambridge) 109: 375-386.

Tamminga, S., P.L. van der Togt, C.J. van der Koelen, C. Meliefste, M. Luttikhuis \& G.D.H. Claassen, 1989. Ruminal behaviour of starches in dairy cows. (In Dutch). Mededelingen No. 14, Research Institute for Livestock Feeding and Nutrition, Lelystad, $106 \mathrm{pp}$.

Tamminga, S. \& A.M. van Vuuren, 1988. Formation and utilisation of end products of lignocellulose degradation in ruminants. Animal Feed Science and Technology 21: 141-159.

Tamminga, S, A.M. van Vuuren, C.J. van der Koelen, R.S. Ketelaar \& P.L. van der Togt, 1990. Ruminal behaviour of structural carbohydrates and non-structural carbohydrates and crude protein from concentrate ingredients in dairy cows. Netherlands Journal of Agricultural Science 38: 513-526.

Thomas, C., K. Aston, S.R. Daley \& J. Bass, 1986. Milk production from silage. 4. The effect of the composition of the supplement. Animal Production 42: 315-325.

Visser, H. de \& A.M. de Groot, 1980. The influence of the starch and sugar content of concentrates on feed intake, rumen fermentation, production and composition of milk. In. D. Giesecke, G. Dirksen and M. Stangassinger (Eds). Proceedings of th $\mathrm{IV}^{\text {th }}$ International Conference on Production Disease in Farm Animals, p. 41-48. Munich, Tierärzliche Fakultät der Universität.

Visser, H. de \& S. Tamminga, 1987. Influence of wet versus dry by-product ingredients and addition of branched-chain fatty acids and valerate to dairy cows. 1. Feed intake, milk production and milk composition. Netherlands Journal of Agricultural Science 35: 163-175.

Visser, H. de \& V.A. Hindle, 1990a. Dried beet pulp, pressed beet pulp and maize silage as substitutes for concentrates in dairy cow rations. 1. Feeding value, feed intake, milk production and milk composition. Netherlands Journal of Agricultural Science 38: 77-88.

Visser, H. de, H. Huisert \& R.S. Ketelaar, 1991. Dried beet pulp, pressed beet pulp and maize silage as substitutes for concentrates in dairy cow rations. 2. Feed intake, fermentation pattern and ruminal degradation characteristics. Netherlands Journal of Agricultural Science 39: 21-30.

Visser, H. de, H. Huisert, A. Klop \& R.S. Ketelaar, 1992. Autumn-cut grass silage as roughage component in dairy cow rations. 2. Rumen degradation, fermentation and kinetics. Netherlands Journal of Agricultural Science. Submitted for publication.

Visser, H. de, P.L. van der Togt \& S. Tamminga, 1990b. Structural and non-structural carbohydrates in concentrate supplements of silage-based dairy cow rations. 1. Feed intake and milk production. Netherlands Journal of Agricultural Science 38: 487-498.

Visser. H. de \& A. Steg, 1988. Utilisation of by-products for dairy cow feeds. In: P.C. Garnsworthy 
(Ed), Nutrition and lactation in the dairy cow. p. 378-394, Butterworth, London.

Vuuren, A.M., K. Bergsma, F. Krol-Kramer \& J.A.C. van Beers, 1989. Effects of addition of cell wall degrading enzymes on the chemical composition and the in sacco degradation of grass silage. Grass and Forage Science 44: 223-230.

Vuuren, A.M., F. Krol-Kramer, R.A. van der Lee \& H. Corbijn, 1992. Protein digestion and intestinal amino acids in dairy cows fed fresh Lolium perenne with different nitrogen contents. Journal of Dairy Science 75: in press

Vuuren, A.M. van, S. Tamminga \& R.S. Ketelaar, 1990. Ruminal availability of nitrogen and carbohydrates from fresh and preserved herbage in dairy cows. Netherlands Journal of Agricultural Science 38: 499-512.

Waldo, D.R. 1973. Extent and partition of cereal grain starch digestion in ruminants. Journal of Animal Science 37: 1062-1074. 